\title{
EFFECT OF MANNAN OLIGOSACCHARIDES ON RABBIT PERFORMANCE, DIGESTIBILITY AND RECTAL BACTERIAL ANAEROBIC POPULATIONS DURING AN EPISODE OF EPIZOOTIC RABBIT ENTEROPATHY
}

\author{
Bovera F.", Nizza S. ${ }^{\dagger}$, Marono S.", Mallardo K. ${ }^{\dagger}$, Piccolo G.*, Tudisco R. , De Martino L. ${ }^{\dagger}$, Nizza A." \\ "Department of Scienze Zootecniche e Ispezione degli Alimenti, Faculty of Veterinary Medicine, University of Napoli Federico II, \\ Via F. Delpino, 1. 80137 NAPOLI. Italy. \\ †Department of Patologia e Sanità Animale, Faculty of Veterinary Medicine, University of Napoli Federico II, Via F. Delpino, 1. \\ 80137 NAPOLI. Italy.
}

\begin{abstract}
АвstRAct: The effect of three levels of mannan oligosaccharides (MOS at 0.5, 1.0 and $1.5 \mathrm{~g} / \mathrm{kg}$ diet) compared to dietary antibiotic supplementation (ANT, colistin sulphate 144, tylosin 100 and oxytetracycline $1000 \mathrm{ppm}$ ) and to a diet without MOS or medication (control group) were studied on 5 groups of rabbits ( $n=342$ cages/group and 2 rabbits/ cage) from weaning ( $35 \mathrm{~d}$ ) to $60 \mathrm{~d}$ of age in a farm with an anamnestic history of Epizootic Rabbit Enteropathy (ERE). Mortality rate was recorded daily. Thirty two cages per group were randomly chosen to record growth performance and rectal anaerobic microbial population. Live weight and feed intake were recorded weekly. At $49 \mathrm{~d}$ of age rectal swabs were collected with cotton swabs from 8 rabbits per group and the anaerobic microbial population was counted. Feed digestibility was determined per cage using acid insoluble ash as an internal marker, collecting faeces from 57 to $59 \mathrm{~d}$ of age. An episode of ERE occurred during the second and the third week of the trial. The control group showed a high mortality rate during the fattening period $(78 \%)$ and was not considered for further measurements. Total mortality rate was higher $(P<0.05)$ for rabbits fed antibiotics $(34.2 \%)$ than for those fed MOS $(17.7,7.75$ and $17.1 \%$, for MOS at 0.5 , 1.0 and $1.5 \mathrm{~g} / \mathrm{kg}$ diet, respectively), with the lowest mortality rate being for those with a $1.0 \mathrm{~g} \mathrm{MOS} / \mathrm{kg}$ diet. Medicated rabbits showed similar growth rates compared to the average of those fed MOS diets (38.6 g/d on average), but impaired feed conversion ratio (FCR) and nutrient digestibility $(P \leq 0.003)$. Rabbits fed MOS at $1.0 \mathrm{~g} / \mathrm{kg}$ showed better growth rates, FCR and nutrient digestibility $(P \leq 0.01)$ than those fed $1.5 \mathrm{~g} / \mathrm{kg}$ MOS. Total anaerobic and Clostridium spp. counts were higher in medicated animals compared to those fed MOS, with those fed $1 \mathrm{~g} / \mathrm{kg} \mathrm{MOS} \mathrm{showing} \mathrm{the} \mathrm{lowest}$ value $(P<0.001)$. Under critical conditions due to an episode of ERE, a concentration of $1.0 \mathrm{~g} / \mathrm{kg} \mathrm{MOS}$ in the diet, could reduce rabbit mortality and improve growth performance.
\end{abstract}

Key Words: rabbit, epizootic rabbit enteropathy, mannan-oligosaccharides, antibiotics.

\section{INTRODUCTION}

The period around weaning (28-35 d of age) is very critical in rabbit production, in particular under intensive farming conditions. In these conditions, the digestive system of young rabbits can be considered to be in a status of unstable balance, which a combination of factors (diet, environment and management stressors as indicated by Casagrande-Proietti et al., 2009) can modify, thereby increasing rabbit susceptibility to post-weaning digestive disorders. Specific pathogens such as Escherichia coli O103 or Clostridium spiriforme can lead to high post-weaning mortality rates (higher than $20 \%$, Peeters et

Correspondence: F. Bovera, bovera@unina.it

Received June 2009 - Accepted December 2009 
al., 1995). Presently, the most common disorder in rabbit production is the occurrence of a complex enteritis (Epizootic Rabbit Enteropathy, ERE) which is the first cause of mortality in the European rabbit industry (Dewree et al., 2003). However, no pathogenic agent has been identified to date (Licois et al., 2000; Marlier et al., 2006; Szalo et al., 2007; Huybens et al., 2009). To prevent post-weaning digestive disorders, prophylactic antimicrobial medication is normally used in growing rabbits. However, the wide use of antibiotics (not only in animal production) has led to the occurrence of antibiotic resistant bacteria (Falcao-e-Cunha et al., 2008). Consequently, in January 2006 the European Community banned the use of antibiotics as growth promoters. Prebiotics and in particular mannan oligosaccharides (MOS, derived from the outer cell wall of the Saccharomyces cerevisiae yeast) are considered to be a promising alternative to antibiotics (Kocher, 2006). Fonseca et al. (2004) recorded a reduction in mortality with 2 $\mathrm{g} / \mathrm{kg}$ MOS in the diet compared to oxytetracycline supplementation (1000 ppm) with no effect on rabbit growth performance. However, Mourao et al. (2006) found no differences between MOS (1.0, 1.5 and $2.0 \mathrm{~g} / \mathrm{kg})$ and $\mathrm{Zn}$ bacitracin $(0.1 \mathrm{~g} / \mathrm{kg})$ for mortality and growth rate, probably due to the relatively low mortality rate (from 1 to $9 \%$ ) observed. Besides dietary MOS supplementation (2.0 and $1.0 \mathrm{~g} / \mathrm{kg}$ MOS) stimulated intestinal villi development and caecal volatile fatty acid concentrations and reduced caecal pH (Pinheiro et al., 2004; Mourao et al., 2006). Guedes et al. (2009) also found that the addition of 2.0 $\mathrm{g} / \mathrm{kg}$ MOS to the diet increased VFA concentration in the caecum of growing rabbits, but Pinheiro et al. (2009) observed that $1.0 \mathrm{~g} \mathrm{MOS} / \mathrm{kg}$ was not able to reduce the negative effects of low fibre diets on rabbit growth performance. The aim of the present research was to evaluate the effect of diets based on mannanoligosaccharides at different levels $(0.5,1.0$ and $1.5 \mathrm{~g} / \mathrm{kg}$ of diet) compared to antibiotic supplementation on rabbit in vivo performance, feed digestibility and rectal microbial anaerobe populations from 35 to 60 d during an episode of Epizootic Rabbit Enteropathy (ERE).

\section{MATERIAL AND METHODS}

\section{Diets}

The basal diet was a commercially manufactured diet normally used on the farm (ingredients: dehydrated alfalfa meal, wheat middling, sunflower meal, alfalfa hay, maize, sugar cane molasses, toasted soybean meal, calcium carbonate, salt, soybean oil) with a chemical composition, expressed as percentage of dry matter, as follows: dry matter 87.5 , ash 10.9 , crude protein 16.5 , ether extract 3.43 , crude fibre 21.6 , neutral detergent fibre 34.1, acid detergent fibre 25.7, acid detergent lignin 3.57. The diet containing antibiotics (ANT, colistin sulphate 144, tylosin 100, and oxytetracycline $1000 \mathrm{mg} / \mathrm{kg}$ ), normally used in the farm under veterinarian prescription, was considered as a positive control. A negative control group was obtained by feeding rabbits with the same diet without additives. Three experimental treatments were obtained by supplementing the common basal diet (negative control) with: (1) MOS0.5 (Bio$\operatorname{Mos}^{\circledR}$, Alltech Inc., USA at $0.5 \mathrm{~g} / \mathrm{kg}$ ); (2) MOS1.0 (Bio-Mos ${ }^{\circledR}$ at $1.0 \mathrm{~g} / \mathrm{kg}$ ); (3) MOS1.5 (Bio-Mos ${ }^{\circledR}$ at $1.5 \mathrm{~g} / \mathrm{kg})$.

\section{Animals and housing}

The trial was carried out on a commercial rabbit farm with an anamnestic history of Epizootic Rabbit Enteropathy (ERE), located in the South of Italy. A total of 3,420 weaned (35 d) hybrid Hyla rabbits were randomly divided among 5 groups (684 rabbits/group) in the same building, and placed in bicellular cages $(26 \times 46 \times 35 \mathrm{~cm}$ high, 2 rabbits/cage, $342 \mathrm{cages} /$ group). Up to $60 \mathrm{~d}$ of age, mortality rate was recorded daily for the entire group. Thirty two cages per treatment, a total of 320 rabbits, weighing on average $751.7 \pm 3.90 \mathrm{~g}$ (mean \pm standard error), sex ratio $1: 1$, were randomly chosen to measure live weight and feed intake from 35 to $60 \mathrm{~d}$, and nutrient digestibility from 57 to $59 \mathrm{~d}$ of age. Each morning, before feed distribution, dead rabbits and/or rabbits with symptoms of disease (diarrhoea) in a subgroup were removed 
and the cages in which one or both rabbits were removed were excluded from the trial. Individual live weight and feed intake per cage were recorded weekly in order to calculate daily weight gain, daily feed intake and feed conversion ratio (FCR). For these calculations only cages with no eliminated rabbits were considered.

\section{Experimental procedure}

At $49 \mathrm{~d}$ of age, one week after the outbreak of ERE in the farm, rectal material was sampled using cotton swabs from 8 healthy animals per treatment at 13:00 h. Rabbits were removed from the cages and a cotton swab was introduced into the rectum to collect rectal samples. Because cotton sticks do not allow collection of exact amounts of rectal material, samples were taken on three consecutive days on the same rabbits and the average results were used for statistical analysis. Only in three cases rectal samples were collected two times (dead animal). Swabs had a transport system for anaerobes (BBL culture swab plus amines single applicator, BD). In the laboratory (around $1 \mathrm{~h}$ after collection) the swabs were introduced in an anaerobic chamber and directly submitted to serial dilutions using a peptone solution (Oxoid CM0009B). The same cultural medium and the method to obtain anaerobic conditions were used for all the cultured anaerobes. From each dilution, $0.1 \mathrm{~mL}$ were spread on plates of Schaedler Blood agar (+Emina and vit. K, Oxoid PB5034A). The plates were incubated under anaerobic conditions for $24 \mathrm{~h}$ at $37^{\circ} \mathrm{C}$, using anaerobic jars with an anaerobic atmosphere generation system (AN0025 Oxoid). The total count of anaerobes was obtained for the different types of colonies cultured, and identified according to their morphological and biochemical characteristics using established bacteriological criteria (Neut et al., 1997). In particular, suspect colonies were picked from a plate and were phenotypically identified on the basis of Gram stain morphology, indole negative and catalase positive: Clostridium species are obligate anaerobes producing endospores, gram positive, very often pleomorphic and usually catalase negative; $\mathrm{Cl}$. perfringens is indole negative and on the plate has cream colonies with double zone of haemolysis; $\mathrm{Cl}$. hystoliticum is aerobic-tolerant, forms colonies on blood agar plates and is not haemolytic. Enzyme profiles were generated with the Rapid ID 32A identification system for anaerobes, according to the manufacturer's instructions (Rapid ID 32 A 32300 Biomerieux).

The apparent digestibility coefficients of organic matter (OM), crude protein (CP), ether extract (EE) and crude fibre (CF) were measured using acid insoluble ash (AIA) as an inert marker. The faeces were collected on three consecutive days ( 57 - $59 \mathrm{~d}$ of age) using nylon nets placed under the cages used for the growth trial $(25,28,26$ and 22 cages respectively for groups MOS0.5, MOS1.0, MOS1.5, ANT). Fresh faeces were dried in a draft oven at $60{ }^{\circ} \mathrm{C}$ to constant weight, then analysed. The calculation of apparent digestibility coefficients; was made as follows: $100 \times[(\%$ AIA in the faeces $/ \%$ nutrient in the faeces $)-(\%$ AIA in the feed $/ \%$ nutrient in the feed $)] /(\%$ AIA in the faeces $/ \%$ nutrient in the faeces $)$.

\section{Chemical analysis}

Chemical analyses of experimental diets were performed using the following AOAC procedures (2004): dry matter (934.01), ether extract (920.39), ash (942.05) and crude protein (954.01), crude fibre (945.18), acid detergent fibre and acid detergent lignin (973.18), amylase treated neutral detergent fibre (2002.04). Acid insoluble ashes on faecal and feed samples were determined in accordance with Vogtmann et al. (1975).

\section{Statistical analysis}

Data were analysed by ANOVA (SAS, 2000) using a one-way model to test the effect of different additives in the concentrate. Bacterial concentrations were subjected to $\log _{10}$ transformation before statistical analysis in order to normalize distribution. Means were compared using orthogonal contrasts. In particular, three contrasts were studied: ANT $v s$. average of all MOS groups (0.5, 1.0 and 1.5), MOS0.5 
vs. average of MOS1.0+1.5 groups and MOS1.0 vs. MOS1.5 group. Mortality rates were analysed using the chi-square test.

\section{RESULTS}

During the second and the third week of the trial (from 42 to $56 \mathrm{~d}$ of age) an episode of Epizootic Rabbit Enteropathy occurred and mortality rate on the rabbit farm exceeded $35 \%$. In the farm where the trial was carried out, rabbits usually received the same medication (under veterinarian prescription) as the ANT group in order to prevent digestive disorders. The control group, fed without additives, showed a mortality rate higher than $78 \%$ and survivor animals showed severe symptoms of intestinal disease. For this reason, it was not possible to perform the scheduled measurements, and the control group was excluded from the trial.

Mortality rates in each subgroup (32 cages) of animals, used to record growth rate, was similar to that recorded in the total group, (342 cages) used to record mortality rate. To avoid the inclusion of unhealthy animals in the growth trial, cages in which one or two animals died or showed signs of disease (diarrhoea), were discarded from statistical analysis.

The mortality rate (Table 1) was equal to zero during the first week of the trial for all the groups. For the two successive weeks, when the episode of ERE occurred, the percentage of mortality showed high values. In group MOS1.0 no rabbit deaths were observed up to two weeks later, when the episode of ERE abated intensity in the other three groups. During the two "critical" weeks, the ANT group showed the highest value for mortality rate.

Growth traits had a different trend throughout the trial due to the ERE outbreak (Table 2). However, considering the average values over the entire period (35 - $60 \mathrm{~d})$, the ANT group showed no differences compared to the three MOS groups, while MOS1.0 group had a higher growth rate than MOS1.5 group $(P<0.001)$. No differences were observed for MOS0.5 vs. MOS1.0+1.5 groups $(P=0.99)$. During all the weeks of the trial, rabbits from the ANT group showed a daily feed intake different to that of the MOS groups. In particular, during the first week feed intake was lower than with the MOS groups $(P<0.001)$, but it was higher in the successive weeks and over the whole trial $(P<0.001)$. MOS0.5 group showed a feed intake lower than the other MOS groups during the first, the second and the last week of the trial $(P<0.001)$. Considering the whole experimental period, the MOS0.5 group showed no significant effect on feed intake compared to other MOS groups $(P=0.090)$. Feed intake from 49 to $56 \mathrm{~d}$ and onwards for the MOS1.0 group was lower than the MOS1.5 group, and this difference was also recorded throughout the whole fattening period.

According to the variability in the daily weight gain and feed intake, feed conversion ratio showed a different trend throughout the trial. Considering the period 35 - $60 \mathrm{~d}$ the ANT group showed a higher value

Table 1: Effect of medication and MOS supplementation on mortality rate $(\%)$ throughout the trial $(n=684 /$ group).

\begin{tabular}{lccccc}
\hline Treatment $^{1}$ & 35 to $42 \mathrm{~d}$ & 42 to $49 \mathrm{~d}$ & 49 to $56 \mathrm{~d}$ & 56 to $60 \mathrm{~d}$ & 35 to $60 \mathrm{~d}$ \\
\hline ANT & 0 & $12.72^{\mathrm{c}}$ & $15.50^{\mathrm{c}}$ & $6.29^{\mathrm{b}}$ & $34.20^{\mathrm{c}}$ \\
MOS0.5 & 0 & $11.40^{\mathrm{c}}$ & $6.29^{\mathrm{b}}$ & $0^{\mathrm{a}}$ & $17.69^{\mathrm{b}}$ \\
MOS 1.0 & 0 & $0^{\mathrm{a}}$ & $0^{\mathrm{a}}$ & $7.75^{\mathrm{b}}$ & $7.75^{\mathrm{a}}$ \\
MOS 1.5 & 0 & $8.19^{\mathrm{b}}$ & $8.92^{\mathrm{b}}$ & $0^{\mathrm{a}}$ & $17.10^{\mathrm{b}}$ \\
\hline
\end{tabular}

${ }^{1}$ MOS0.5, MOS1.0 and MOS1.5 diets including mannan oligosaccharides at 0.5, 1.0 and $1.5 \mathrm{~g} / \mathrm{kg}$; ANT: diet including antibiotics. Mean values in the same column not sharing the same superscript differ at $P<0.05$. 
Table 2: Effect of medication and MOS supplementation on daily weight gain $(\mathrm{g} / \mathrm{d})$, average daily feed intake $(\mathrm{g} / \mathrm{d})$ and feed conversion ratio $(\mathrm{g} / \mathrm{g})$ in rabbits from 35 to $60 \mathrm{~d}$.

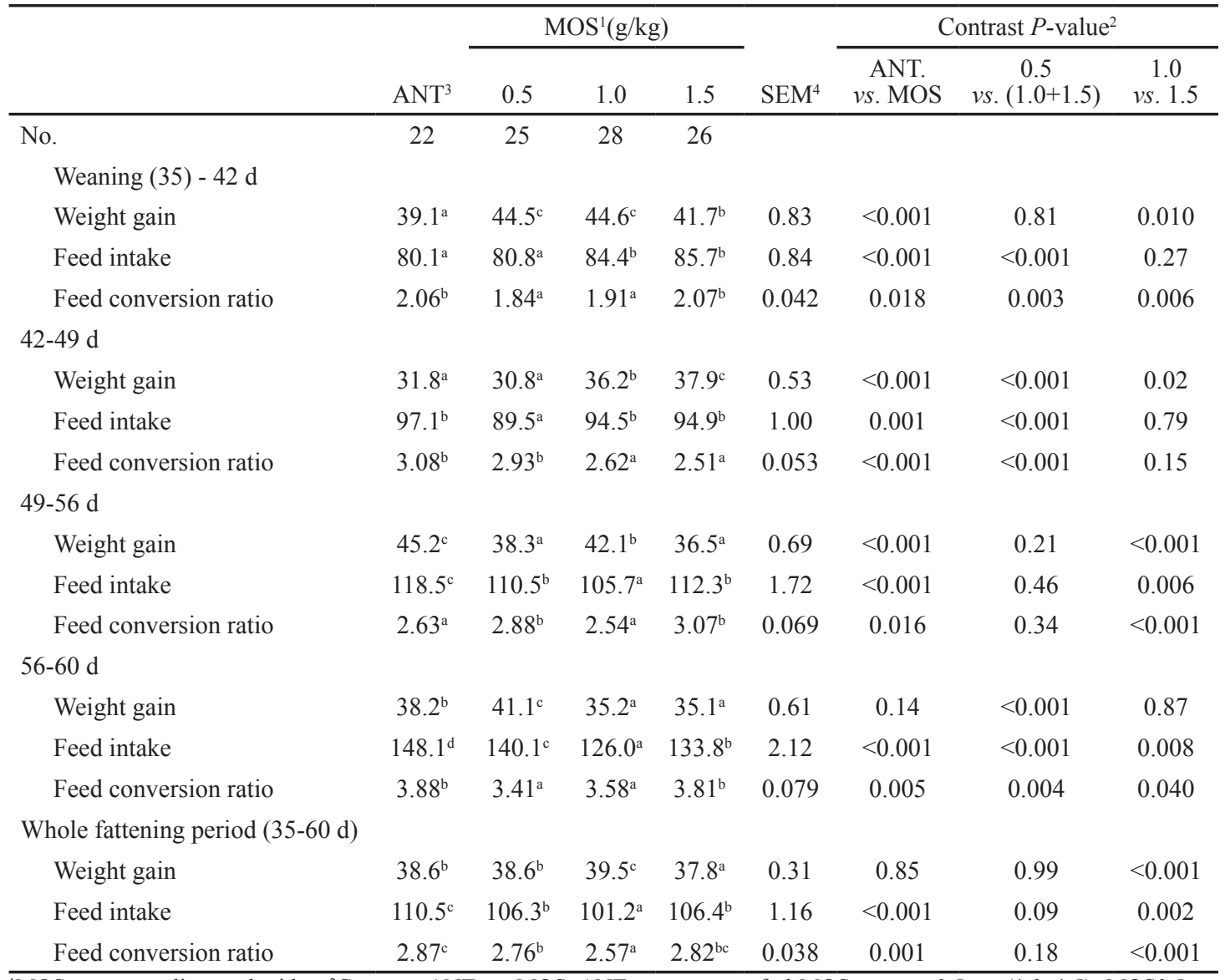

${ }^{1}$ MOS: mannan oligosaccharides. ${ }^{2}$ Contrast: ANT $v s$. MOS, ANT $v s$. average of al MOS groups; $0.5 v s .(1.0+1.5)$, MOS0.5 vs. average of $\operatorname{MOS}(1.0+1.5) ; 1.0$ vs. 1.5, MOS1.0 vs. MOS1.5. ${ }^{3} \mathrm{ANT}$ : diet including antibiotics, ${ }^{4} \mathrm{SEM}$ : standard error or means.

Mean values in the same row not sharing the same superscript differ at $P<0.05$.

than the MOS groups $(P=0.001)$, the MOS0.5 group showed no differences from the MOS1.0 and 1.5 groups, whereas the MOS1.0 group showed a lower FCR than the MOS1.5 group $(P<0.001)$.

Rabbits from the ANT group showed the lowest apparent digestibility coefficients for the organic matter, crude protein and crude fibre (Table 3). Values of nutrient digestibility are in line with those reported by Cesari et al. (2009). Orthogonal contrast analysis showed no differences between the MOS0.5 and MOS1.0+1.5 groups for OM, CP and EE digestibility, whereas for CF digestibility the MOS0.5 group showed lower values than the MOS1.0+1.5 groups. The MOS1.0 group always had higher apparent faecal digestibility values than the MOS1.5 group.

The rectal swabs from rabbits in the ANT group had higher levels of total anaerobes, Clostridium spp. and $\mathrm{Cl}$. hystoliticum than the MOS groups $(P<0.001$, Table 4). The MOS0.5 group showed higher levels of total anaerobes and Clostridium spp. but lower levels of $C l$. hystoliticum than MOS1.0+1.5 groups $(P<0.001)$. MOS1.0 showed lower values of total anaerobes, Clostridium spp. and Cl. hystoliticum than 
Table 3: Effect of medication and MOS supplementation on apparent faecal digestibility (\%) of organic matter, crude protein, ether extract and crude fibre measured using the acid insoluble ash system.

\begin{tabular}{|c|c|c|c|c|c|c|c|c|}
\hline & \multirow[b]{2}{*}{$\mathrm{ANT}^{3}$} & \multicolumn{3}{|c|}{$\operatorname{MOS}^{1}(\mathrm{~g} / \mathrm{kg})$} & \multirow[b]{2}{*}{ SEM $^{4}$} & \multicolumn{3}{|c|}{ Contrast $P$-value ${ }^{2}$} \\
\hline & & 0.5 & 1.0 & 1.5 & & $\begin{array}{c}\text { Ant. } \\
\text { vs. MOS }\end{array}$ & $\begin{array}{c}0.5 \\
\text { vs. }(1.0+1.5)\end{array}$ & $\begin{array}{c}1.0 \\
\text { vs. } 1.5\end{array}$ \\
\hline No. & 22 & 25 & 28 & 26 & & & & \\
\hline \multicolumn{9}{|l|}{ Digestibility } \\
\hline Organic matter & $51.1^{\mathrm{a}}$ & $53.8^{\mathrm{b}}$ & $55.8^{\mathrm{c}}$ & $52.7^{\mathrm{ab}}$ & 0.64 & $<0.001$ & 0.63 & $<0.001$ \\
\hline Crude protein & $70.5^{\mathrm{a}}$ & $72.3^{\mathrm{a}}$ & $74.1^{\mathrm{b}}$ & $72.0^{\mathrm{a}}$ & 0.61 & 0.003 & 0.34 & 0.010 \\
\hline Ether extract & $85.1^{\mathrm{a}}$ & $85.8^{\mathrm{a}}$ & $87.6^{\mathrm{b}}$ & $84.3^{\mathrm{a}}$ & 0.58 & 0.23 & 0.88 & $<0.001$ \\
\hline Crude fibre & $21.6^{\mathrm{a}}$ & $23.1^{\mathrm{a}}$ & $24.9^{\mathrm{b}}$ & $22.9^{\mathrm{a}}$ & 0.62 & $<0.001$ & 0.020 & $<0.001$ \\
\hline
\end{tabular}

${ }^{1}$ MOS: mannan oligosaccharides. ${ }^{2}$ Contrasts as in Table $2 .{ }^{3}$ ANT: diet including antibiotics. ${ }^{4}$ SEM: standard error or means.

Mean values in the same row not sharing the same superscript differ at $P<0.05$.

MOS1.5 group. The level of $C l$. perfringens was not submitted to statistical elaboration (and not reported in the table) because it was only detected in 3 rabbits in the ANT group (37.5\%) and in 1 rabbit in the MOS0.5 and 1.5 groups $(12.5 \%)$ whereas no colonies were isolated in the caecal content from the MOS1.0 rabbit group. The results obtained for $C l$. perfringens were $0.23,0.14$ and $0.04 \log _{10} \mathrm{CFU} / \mathrm{swab}$, for ANT, MOS 0.5 and MOS 1.5 groups, respectively.

\section{DISCUSSION}

Our results suggest that, under the condition of ERE, mannan oligosaccharides seem more able to prevent mortality than the medication used in this study. In fact, mortality in treatments with antibiotics was higher than that in MOS groups.

The lower effectiveness of antibiotics than mannan-oligosaccharides in the control of mortality rate could be justified by an antimicrobial-resistance of the bacteria involved in this pathology (Marlier et al., 2006). Mannan oligosaccharides are able to bind the mannose receptors on the type 1 fimbriae of some pathogen bacteria (as Escherichia coli and Salmonella enteritidis) in order to prevent their attachment to intestinal mucosa (Spring et al., 2000; Firon et al., 1983). The maintenance of better conditions in intestinal lumen can prevent the proliferation of $\mathrm{Cl}$. perfringens. The concentration of $1.0 \mathrm{~g} / \mathrm{kg}$ of MOS in the diet was the best way to reduce the mortality rate down to a normal level. Mannan-oligosaccharides at 0.5 or $1.5 \mathrm{~g} /$ $\mathrm{kg}$ in the diet reduced mortality rates compared to the ANT group but were not able to achieve mortality percentage rates close to that of the MOS1.0 group. It can be hypothesized that, for the MOS0.5 group, the

Table 4: Effect of medication and MOS supplementation on total anaerobes, Clostridia spp. and Clostridium hystoliticum concentration in rabbit rectal swabs ( $\mathrm{n}=8 /$ group).

\begin{tabular}{|c|c|c|c|c|c|c|c|c|}
\hline & & \multicolumn{3}{|c|}{$\operatorname{MOS}^{1}(\mathrm{~g} / \mathrm{kg})$} & & \multicolumn{3}{|c|}{ Contrast $P$-value ${ }^{2}$} \\
\hline & $\mathrm{ANT}^{3}$ & 0.5 & 1.0 & 1.5 & $\mathrm{SEM}^{4}$ & $\begin{array}{c}\text { Ant. } \\
\text { vs. MOS }\end{array}$ & $\begin{array}{c}0.5 \\
\text { vs. }(1.0+1.5)\end{array}$ & $\begin{array}{c}1.0 \\
\text { vs. } 1.5\end{array}$ \\
\hline Total anaerobes & $6.85^{\mathrm{c}}$ & $6.36^{\mathrm{b}}$ & $5.51^{\mathrm{a}}$ & $6.15^{\mathrm{b}}$ & 0.08 & $<0.001$ & $<0.001$ & $<0.001$ \\
\hline Clostridia spp. & $5.37^{\mathrm{c}}$ & $5.25^{\mathrm{bc}}$ & $4.23^{\mathrm{a}}$ & $5.17^{\mathrm{b}}$ & 0.06 & $<0.001$ & $<0.001$ & $<0.001$ \\
\hline Clostridium hystoliticum & $3.92^{\mathrm{d}}$ & $1.14^{\mathrm{a}}$ & $1.51^{\mathrm{b}}$ & $1.71^{\mathrm{c}}$ & 0.02 & $<0.001$ & $<0.001$ & $<0.001$ \\
\hline
\end{tabular}

${ }^{1}$ MOS: mannan oligosaccharides. ${ }^{2}$ Contrasts as in Table $2 .{ }^{3}$ ANT: diet including antibiotics. ${ }^{4}$ SEM: standard error or means. Mean values in the same row not sharing the same superscript differ at $P<0.05$. 
low concentration of mannan-oligosaccharides in the diet was not enough to bind the pathogens, but it is difficult to explain why MOS at $1.5 \mathrm{~g} / \mathrm{kg}$ did not induce similar or better results than MOS1.0 rabbits. The reason might be related with an interaction of a higher level of MOS with saprophyte bacteria, thereby also reducing their chances of attachment to the intestinal mucosa.

Surprisingly, it was not possible to identify Bacteroides spp. which normally dominates the intestinal flora of rabbits (Licois, 1998). In rabbits that died of ERE, it was able to isolate Bacteroides from caecal content only in a very small number of animals, whereas in almost all dead rabbits $\mathrm{Cl}$. perfringens was isolated. In our study, the rectal swabs that were analysed were collected from rabbits without clinical disease symptoms. However, the absence of evident signs of disease does not necessarily indicate a healthy status of the gastro-intestinal tract. Several authors (Le Normand et al., 2003; Dewrée et al., 2003; Marlier et al., 2003, 2006; Cesari et al., 2009) have also showed that $C l$. perfringens may play a major role in this pathology because of its important proliferation in the digestive tract when animals are affected by ERE. Romero et al. (2009) also found that the caecal content concentration of Clostridium perfringens recorded $14 \mathrm{~d}$ after weaning was closely related $\left(\mathrm{R}^{2}=0.961 ; P<0.001\right)$, to the mortality rate due to ERE, by applying a quadratic regression equation.

The higher values of digestibility coefficients in the MOS1.0 group for almost all the tested nutrients suggest more efficient utilisation of the nutrient in the intestinal tract, that contributes to a more favourable feed conversion ratio compared to the other groups. Several authors (Pinheiro et al., 2004, Mourao et al., 2006) reported that MOS increased the length of villi at the ileum, possibly as a result of impriving the intestinal environment compared to rabbits fed without additives. Better development of intestinal villi can justify the higher feed utilisation of MOS1.0 rabbits.

The MOS1.5 group showed feed digestibility coefficients for all the nutrients (OM, CP, EE, CF) lower than the MOS1.0 group, suggesting that the intenstinal environment was not completely positive. Furthermore, the MOS0.5 group always showed lower digestibility coefficients than the MOS1.0 group. Volek et al. (2007) found lower mortality rates with rabbits weaned at $25 \mathrm{~d}$ of age and fed MOS at $3 \mathrm{~g} / \mathrm{kg}$ and also lower digestibility coefficients (measured at $40 \mathrm{~d}$ of age) for organic matter, crude protein and cellulose compared to the control group (without additives).

Mourao et al. (2006) found no differences in feed conversion ratio in rabbits fed antibiotics compared to those fed MOS at three different concentrations $(1.0,1.5$ and $2.0 \mathrm{~g} / \mathrm{kg})$, whereas the MOS groups showed significantly $(P<0.05)$ lower feed conversion ratios than the control group without additives. However, this trial was made on a rabbit farm in which the mortality rate in the group fed without additives was 8.75 $\%$, indicating a good health status in the building.

\section{CONCLUSIONS}

Under critical conditions due to an episode of Epizootic Rabbit Enteropathy, mannan-oligosaccharides showed a positive effect on rabbit mortality rate, growth performance and nutrient digestibility. The best results were obtained with a concentration of $1.0 \mathrm{~g} / \mathrm{kg}$ diet of MOS.

\section{REFERENCES}

AOAC. 2004. Official methods of analysis ( $18^{\text {th }}$ ed.), Association of Official Analytical Chemists. 2 vol., AOAC, Arlington, VA, USA.

Casagrande Proietti P., Dal Bosco A., Hilbert F., Franciosini M.P., Castellini C. 2009. Evaluation of intestinal bacterial flora of conventional and organic broilers using culture-based methods. Ital. J. Anim. Sci., 8: 51-63.

Cesari V., Grilli G., Ferrazzi V., Toschi I. 2009. Influence of age at weaning and nutritive value of weaning diet on growth performance and caecal traits in rabbits. World Rabbit Sci., 17: 199-205.
Dewree R., Licois D., Coudert P., Lassence C., Vindevogel H., Marlier D. 2003. L'entéropathie épizootique du lapin (EEL): étude du rôle des infections par Clostridium perfringens dans l'étio-pathogénie de ce syndrome. In Proc.: $10^{\text {emes }}$ Journées de la Recherche Cunicole, November, 2003. Paris, France. 251-254.

Falcao-e-Cunha L., Castro-Solla L., Maertens L., Marounek M., Pinheiro V., Freire J., Mourao J.L. 2007. Alternatives to antibiotics growth promoters in rabbit feeding: a review. World Rabbit Sci., 15: $127-140$. 


\section{Bovera et al.}

Firon N., Ofek I., Sharon N. 1983. Carbohydrate specificity of the surface lectins of Escherichia coli, Klebsiella pneumoniae, and Salmonella typhimurium. Carbohyd. Res., 120: 235-249.

Fonseca A.P., Falcao L., Kocher A., Spring P. 2004. Effect of dietary mannan oligosaccharide in comparison to oxitetracyclin on performance of growing rabbits. In Proc.: $8^{\text {th }}$ World Rabbit Congress, 7-10 September, 2004. Puebla, Mexico.829-833.

Guedes C.M., Mourao J.L., Silva S.R., Gomes M.J., Rodrigues M.A.M., Pinheiro V. 2009. Effect of age and mannan oligosaccharides supplementation on production and volatile fatty acids in the caecum of rabbits. Animal Feed Sci. Technol., 150: 330-336.

Huybens N., Houeix J., Licois D., Mainil J., Marlier D. 2009. Inoculation and bacterial analyses of fractions obtained from the reference inoculum TEC4 which experimentally reproduces epizootic rabbit enteropathy. World Rabbit Sci., 17: 185-193.

Kocher A. 2006. Interfacing gut health and nutrition: the use of dietary pre and probiotics to maximize growth performance in pigs and poultry. In D. Barug, J. de Jong, A.K. Kies, M.W.A. Verstegen (eds.) Antimicrobial growth promoters. Wageningen Academic Publishers, The Netherlands. 289-310.

Le Normand B., Le Guenec J., Moalic P.Y. 2003. Contribution à l'étude toxinotypique des souches de Clostridium perfringens isolées dans l'entéropathie épizootique du lapin (EEL). Relation avec la clinique observée. In Proc.: 10 imes Journées de la Recherche Cunicole, November, 2003. Paris, France. 239-241.

Licois D. 1998. Bilan des travaux réalisés à l'INRA sur l'entérocolite épizootique, dans l'hypothèse d'une étiologie virale de la maladie. In Proc.: $7^{e m e s}$ Journées de la Recherche Cunicole, May, 1998. Lyon, France. 20-25.

Licois D., Coudert P., Ceré N., Vautherot J.F. 2000. Epizootic enterocolitis of the rabbit: review of current research. In Proc. $7^{\text {th }}$ World Rabbit Congress, 4-7 July, 2000, Valencia, Spain. Vol. A: 187-194.

Marlier D., Dewrée R., Licois D., Coudert P., Lassence C., Poulipoulis A., Vindevogel H. 2003. L'Entéropathie Epizootique du Lapin (EEL): un bilan provisoire des résultats après 20 mois de recherches. In Proc.: 10 imes Journées de la Recherche Cunicole, November, 2003. Paris, France. 247-250.

Marlier D., Dewrée R., Lassence C., Licois D., Mainil J., Coudert P., Meulemans L., Ducatelle R., Vindevogel H. 2006. Infectious agents associated with epizootic rabbit enteropathy: isolation and attempts to reproduce the syndrome. Vet. J., 172: 493-500.
Mourao J.L., Pinheiro V., Alves A., Guedes C.M., Pinto L., Saavedra M.J., Spring P., Kocher A. 2006. Effect of mannan oligosaccharides on the performance, intestinal morphology and caecal fermentation of fattening rabbits. Anim. Feed Sci. Technol., 126: 107-120.

Neut C., Guillenot F., Colombel J.F. 1997. Nitrate-Reducing Bacteria in diversion colitis. A clue to inflammation? Dig. Dis. Sci., 42: 2577 2580.

Peeters J.E., Maertens L., Orsenigo R., Colin M. 1995. Influence of dietary beet pulp on caecal VFA, experimental colibacillosis and iota-enterotoxaemia in rabbits. Anim. Feed Sci. Technol., 51: 123139.

Pinheiro V., Alves A., Mourao J.L., Guedes C.M., Pinto L., Spring P. Kocher A. 2004. Effect of mannan oligosaccharides on the ileal morphometry and caecal fermentation of growing rabbits. In Proc.: $8^{\text {th }}$ World Rabbit Congress, 7-10 September, 2004. Puebla, Mexico. 936-941.

Pinheiro V., Guedes C.M., Outor-Monteiro D., Mourao J.L. 2009. Effect of fibre level and dietary mannanoligosaccharides on digestibility, caecal volatile fatty acids and perfromances of growing rabbits. Animal Feed Sci. Technol., 148: 288-300.

Romero C., Nicodemus N., García-Rebollar P., García-Ruiz A.I., Ibáñez M.A., De Blas J.C. 2009. Dietary level of fibre and age at weaning affect the proliferation of Clostridium perfringens in the caecum, the incidence of Epizootic Rabbit Enteropathy and the performance of fattening rabbits. Anim. Feed Sci. Technol., 153: 131-140.

SAS/STAT 2000. Users Guide: Statistics. SAS Institute Inc., Cary, $N C$, USA.

Spring P., Wenk C., Dawson K.A., Newman K.E. 2000. The effects of dietary mannanoligosaccharides on caecal parameters and the concentrations of enteric bacteria in the ceca of salmonellachallenged broiler chicks. Poultry Sci., 79: 205-211.

Szalo I.M., Lassence C., Licois D., Coudert P., Poulipoulis A., Vindevogel H., Marlier D. 2007. Fractionation of the reference inoculum of epizootic rabbit enteropathy in discontinuous sucrose gradient identifies aetiological agents in high density fractions. Vet. J., 173: 652-657.

Vogtmann H., Frirter P., Prabuck A.L. 1975. A new method of determining metabolizability of energy and digestibility of fatty acids in broiler diets. Br. Poult. Sci., 16: 531-534.

Volek Z., Marounek M., Skrivanova V. 2007. Effect of a starter diet supplementation with mannanoligosaccharide or inulin on health status, caecal metabolism, digestibility of nutrients and growth of early weaned rabbits. Animal 1: 523-530. 